\title{
An Exploration of the Nun Kun Mountain Group and Its Glaciers: Discussion
}

Author(s): Thomas Holdich, T. G. Longstaff and Hunter Workman

Source: The Geographical Journal, Vol. 31, No. 1 (Jan., 1908), pp. 39-42

Published by: geographicalj

Stable URL: http://www.jstor.org/stable/1777260

Accessed: 26-06-2016 00:13 UTC

\section{Your use of the JSTOR archive indicates your acceptance of the Terms \& Conditions of Use, available at}

http://about.jstor.org/terms

JSTOR is a not-for-profit service that helps scholars, researchers, and students discover, use, and build upon a wide range of content in a trusted digital archive. We use information technology and tools to increase productivity and facilitate new forms of scholarship. For more information about JSTOR, please contact support@jstor.org.

The Royal Geographical Society (with the Institute of British Geographers), Wiley are collaborating with JSTOR to digitize, preserve and extend access to The Geographical Journal 
$12.45,213^{\circ}$. At 1 , through a thin film of cloud, $217^{\circ}$, not falling when placed vertical, and at $1.5,219^{\circ}$ Fahr. The altitude of Suru is 10,850 feet. As sun-temperatures increase in proportion to altitude, what must the temperatures on these days have been at over 20,000 feet?" * On these, as on other occasions when I have noted high temperatures, the maxima showed themselves in sudden waves or flashes of heat lasting a few moments and then subsiding. It may also be noted that, as on the 18th, some of the highest temperatures have occurred when the sky was covered with thin cirrho-stratus olouds.

Before the paper, the Presrdent : The lecturer of the evening, Dr. Hunter Workman, is going to address us on his last expedition with Mrs. Bullock Workman, his wife, in the Himalayas. I regret that Mrs. Workman has not been able to be here to-night, as we hoped she would have been, because she is engaged in something almost more arduous than climbing 23,000 feet. She is delivering thirty lectures in thirty-seven days, starting from Munich and going by Vienna up to Dresden, Berlin, Hamburg. I need not introduce Dr. Workman to you, because he and Mrs. Workman are old friends of our Society. It is about eight or nine years since they started on their explorations in the Himalayas. Dr. Workman delivered an address here about three years ago on his journey from Srinagar to the sources of the Chogo Lungma glacier. They then returned to the Himalayas, and in the following year Mrs. Bullock Workman gave us a very interesting address. on the earliest exploration ever made of the Hoh Lumba and Sosbon glaciers. To-night, after fresh travels and always on new ground, we are to hear from Dr. Workman an account of their joint ascents in the Nun Kun group. I shall not enter into the difficult question as to what traveller has ascended the greatest height above sealevel. We have Dr. Longstaff here, and I believe there is only a matter of about 10 feet between them, him and Dr. and Mrs. Workman; but I will remind you that all of these explorers are not merely trying how high they can climb. Careful observations are taken of glaciation and in other scientific directions, so that their ascents have real scientific value.

After the paper, Sir Thомаs HoLdich : I am rather glad of this opportunity of expressing my admiration for the consistency and the determination and the ability with which a long record of observations has been taken by Dr. Hunter Workman and his gallant wife-if he will allow me the expression-under circumstances of extreme difficulty. I have had some slight acquaintance with the difficulties and the disabilities which beset the taking of observations in very high altitudes in the Himalayas, and I can only liken it to the conditions under which a man might find himself if he was at sea in very stormy weather, and very sea sick, and was asked suddenly to make records of the height of the waves and the strength of the winds: he would find that it took a great deal of resolution and determination to effect his purpose. It is indeed a most difficult proposition.

There are some of the phenomena to which Dr. Hunter Workman has referred which I had the opportunity of observing, to a certain extent, when I was in the Andes. He referred to the nieves penitentes. Now, although I saw nothing of nieves penitentes in the highest altitudes of the Andes, yet I did observe distinctly the same results, induced probably by the same causes, on the surface of the wide plains which intervene between the Andes and the Atlantic, as I was crossing in winter;

* See the Geographical Journal, March, 1905, p. 260. 
and I was convinced that the cause of the formation which Dr. Hunter Workman puts forward is correct, namely wind-action. I know of no part of the world in which the wind is more persistent from a certain quarter than it is on the western slopes of the Andes and across the intervening plains between the Andes and the Atlantic. The nieves penitentes of the Pampas were most obviously caused by wind. As regards his criticism of the Survey maps, I have very little to say. I can only explain to you, as he must be very well aware, that it is not, and never can be, one of the primary objects of the Survey Department of India to make detailed maps of regions so inaccessible and so remote as those which Dr. Hunter Workman has visited. All I can certainly promise is that the department which is responsible for those maps will receive with the greatest thankfulness any corrections or recommendations that explorers of the type of Dr. Hunter Workman, who take observations carefully and consistently, may possibly give to them.

You must know, for it has been frequently discussed in this hall, the difficulty that exists in determining altitudes at such great heights as those with which Dr. Hunter Workman has been dealing. Barometric observations are notoriously uncertain, and amongst them we must include hypsometric observations, that is, observations obtained by the boiling-point of water, to which Dr. Workman has referred; all are equally affected by variations in atmospheric conditions. There is no doubt that the most certain way of determining the heights of remote and inaccessible peaks is by a process of triangulation, where the angles are actually measured and heights reduced by mathematical processes. But all the same, it must be admitted - and will be admitted by any mathematician-that even so there are uncertainties when it comes to dealing with such enormous altitudes as those of the Himalayan peaks. We do not know exactly, and at present there is no means of determining, what the exact effect of refraction may be in those altitudes; and the result of variation when applied as correction to those observed trigonometrical altitudes may be very considerable. For instance, I may mention that we are still in doubt as to the exact height of the highest mountain in the world, Mount Everest. But we are pretty certain that whatever the correction may be that has to be eventually applied when we are more certain than we are at present of the value of refraction, it will not diminish that height. On the contrary, Mount Everest will probably prove to be some hundred feet or so higher than we at present reckon it. But when we come to the mountains which approach Mount Everest nearest in height, $K_{2}$, which is situated in the north-west of the Himalayas, and that grand peak Kinchinjunga, opposite Darjiling, we are not at present sure which is the highest. We know which is the highest peak in the world, but we do not know the second highest. It may prove-personally, I think it will so prove-that $\mathrm{K}_{2}$ (a peak with which Dr. Hunter Workman is well acquainted), which has always been considered to be the second highest, will prove to be third, and Kinchinjunga will have the honour of ranking szcond.

However that may be, we must all of us accord our unmitigated admiration to the exploits of a lady who has succeeded in exploring such inaccessible altitudes as Mrs. Bullock Workman has done. My admiration for her achierements is unlimited, and I think that, even if it is impossible to say, amongst some four or five people who have ascended higher than any people in the world, which individual amongst them has actually achieved the proud position of getting highest, still we must agree that amongst those few Mrs. Bullock Workman certainly takes a prominent place. Under which circumstances, it is possible that it may be suggested to you, as it has been to me, that it is almost time that a great society like this ranked ladies and men together on precisely the same plane of geographical rescarch. I won't pursue that subject any further; but if any 
movement hereafter should ever take place which would allow ladies as Associates of the Royal Geographical Society to receive the same official recognition as men receive, all I can say is that such a movement would have no warmer supporter than myself.

Dr. T. G. LongstafF : I congratulate Dr. and Mrs. Workman very heartily on the great feat they have performed. I should think that Mrs. Workman's record for altitude will never be beaten by any other lady but herself, and any one who knows what climbing at bigh altitudes means must appreciate the extraordinary degree of fortitude and perseverance with which she is gifted. This ascent of a peak of 23,300 feet by a lady must always rank as one of the most wonderful mountaineering exploits on record. Dr. Workman deserves the thanks of all of us for his self-sacrifice in devoting himself to photography, the results of which have given us such pleasure this evening, instead of completing the ascent, although, of course, he climbed higher than the summit of this peak in 1903.

I must also congratulate my friend Cyprien Savoye and the six Courmayeur porters on the successful accomplishment of a very arduous enterprise. One of the essentials for still higher ascents will be that the man-or lady-who makes the final climb must not be tired out by several days of load-carrying just beforehand; and this plan of having a good supply of the very best professional Alpine porters will no doubt be necessary. In my opinion, not even the Gurkha, with all his pluck, has quite the same stamina for this sort of work as the Alpine peasant, though I, for one, prefer his company.

Dr. Workman has mentioned my name in connection with the greatest altitude at which travellers have encamped, but is not correct in what he has said about me, as he will see if he reads the account of my Tibetan experiences in 1905 in the Alpine Journal (vol. 23, pp. 202-228). If he had read my account, he must have noticed my reference to W. H. Johnson. This gentleman, who belonged to the staff of the G.T.S. of India, and was also a Fellow of this Society, spent a night at over 22,000 feet in the Kuen Lun when surveying beyond the Changchenmo in 1864 (J.R.G.S., 37, pp. 1-47; and Proc. R.G.S., 11, pp. 6-14). But the question of records does not in any way detract from the wonderful feat of endurance performed by Dr. Workman and his wife in spending a night at well over 21,000 feet, after they had already spent three consecutive nights at great altitudes.

Though Dr. Workman does not exaggerate the unpleasant symptoms experienced by most people at high altitudes-indeed, he rather makes light of themI cannot agree with him as to the improbability of the ascent of the highest mountains on the globe, provided always that a relatively easy route exists which is not barred by "questions of high imperial policy." On the Tibetan side of Everest the snow-line probably lies above rather than below 19,000 feet. The rest must be climbed in two days, and this cannot at present be said to be an impossible performance, because both Graham's party and my own, on the final day of the ascent of the two highest mountains that have yet been climbed, were able to ascend nearly 6000 feet and get back to camp for the night. Although I believe that personally I could not climb as high as the summit of Everest, I am equally sure that there are others who can. I wish I was as sure that Englishmen will be permitted to make the attempt.

Dr. Workman's observations on the existence and formation of nieve penitentes and on the relative absence of terminal moraines in this part of the Himalaya, are most interesting and valuable. But in reference to the latter, it seems to me that the action of streams and landslips combine to modify such structures in the Himalaya to a much greater extent than in the Alps or Caucacus, and I have 
several times been puzzled to know whether I was standing on a terminal moraine or not.

The mountaineering obstacles to the success of Dr. and Mrs. Workman's expedition have been great; the extreme steepness of the snow-slopes we have seen on the screen to-night must have frequently subjected them to serious risks from avalanches. I think that the difficulties, and indeed the actual hardships, that are involved in taking photographs and observations at high altitudes, are realized by very few, either of the general public or scientific geographers, and I again congratulate them most heartily on what they have done, and I hope that they will be thoroughly successful in the expedition which I hear they are undertaking next year, and that Mrs. Workman will raise her own record still higher.

Dr. Hunter Workman : In regard to the ease with which Mount Everest can be climbed, granting that any one might climb 7000 feet on Mount Everest, from 15,000 feet to 23,000 feet, I think the next 6000 , from 23,000 to 29,000 , would be a much more difficult affair, because the air is very much more rare the higher you go, and I doubt whether anybody could breathe and undergo the physical strain necessary to climb that last 6000 feet, even if he had the strength. With regard to the suggestion of mountaineers having their camps prepared for them by porters, the question is whether porters could do the work. For reasons given in the paper, I doubt it. As a matter of fact, if the ascent of Mount Everest should be attempted, it is more than likely that its gradients and the natural obstacles would be found to be such as would preclude the possibility of climbing 7000 or 6000 feet in a single day, and a succession of camps would have to be made under the disadvantageous conditions I have mentioned.

The President : In thanking Dr. Hunter Workman for his paper, I need not, I think, say anything more than Sir Thomas Holdich and Dr. Longstaff have said concerning our admiration for the work of himself and Mrs. Workman. I would only ask Dr. Workman to convey this to Mrs. Workman on our behalf.

\section{BATHYMETRICAL SURVEY OF THE FRESH-WATER LOCHS OF SCOTLAND.*} Under the Direction of Sir JOHN MURRAY, K.C.B., F.R.S., D.Sc., etc., and
LAURENCE PULLAR, F.R.S.E.

\section{Part XIII.-Lochs of the Ness Basin.}

THIRD PART.

THE first part of this paper, published in July last, dealt with the physical features of Loch Ness, and the second part, published in October, dealt with twenty-seven of the tributary lochs. This third part includes the descriptions of the remaining five lochs, with summary

* Maps, p. 132. The admirable maps which accompany the three parts of the Ness paper (the last of the series) have been presented by Sir John Murray and Mr. Laurence Pullar, and it is thus due to their liberality that we are able to publish them free of any cost to the Society. Though this is the final contribution to appear in the Journal, the remaining smaller Scottish lochs are to be dealt with in a special publication to be issued, it is hoped, during this year.-President R.G.S. 